\title{
Research on Cash Holdings, Equity Dispersion and Company Performance
}

\author{
Jiakang Wang ${ }^{1}$, Ying Wang ${ }^{2,3}$ \\ 1. School of Economic and Management, Civil Aviation Management Institute of China, Beijing, China, 100102 \\ 2. School of Transportation and Logistics, Southwest Jiaotong University. Chengdu, China, 611756; \\ 3. Beijing National Railway Research \&Design Institute of Signal \&Communication Group Co., Ltd., Beijing, China, \\ 100070 \\ wjksunny@126.com
}

\begin{abstract}
Taking the A-share listed companies of the Shanghai and Shenzhen Stock Exchanges in 2012-2016 as research samples, the article studies the corporate cash holdings behavior and the influence of company performance from the perspective of equity disperse degree. This article is based on two main model, one is cash holding model by Opler (1999), and the other is cash value model by Dittmar and Smith (2007), Faulkender and Wang (2006). The research results show that: (1) the shareholding of cash held by large corporations is relatively small; (2) The dispersion of option did not significantly improve corporate performance, and it also played a negative role. The paper argues that the reasons are as follows: on the one hand, a diversified shareholding structure of the company can form an effective supervision system, push business performance for forward; while on the other hand, it will lead to the final separation of the control over the actual cash flow right, which may result in severe agency conflicts and a major shareholder of the short-selling phenomenon. It is because the negative impact of short-selling is greater than the positive role of supervision, the expected conclusion is reversed.
\end{abstract}

Keywords-Dispersion; Corporate performance; Cash holdings

\section{INTRODUCTION}

In recent years, abundant domestic and international literatures on the phenomenon of cash holdings of listed companies were studied. Trade-off theory points out that the cash hold by the company can bring benefits such as to provide liquidity for the company, but at the same time it may also bear the corresponding opportunity cost. So when marginal revenue of the cash equals its marginal cost held by the company, it exists the optimal revenue cash holdings to the company's. Agency theory believes that the mangers of companies have the condition and motivation to expand their additional power in the company then control more assets to achieve personal or private gains, and the direct manifestation of the power is the dominance of company's free cash. For example, when a company is in the period of mature, it can be able to produce large amounts of stable cash flow. And the shareholders should be paid in cash, but the managers who have control over cash invested a lot of negative net present value (NPV) projects, just because it can achieve personal desire of domination to control the company and to achieve benefits. Therefore, a large amount of cash held by the company can be seen as a signal of managers not good serving the interests of the shareholders [1].
Pecking order theory believes that because the insider of the company and potential outsider investors of the company objectively exists of information asymmetry. On the fact, the more serious of the information asymmetry will exacerbate the difficulty of corporate financing. Thus the cost of corporate financing is higher. In this reality condition, when companies are finding new investment projects, in order to avoid the lack of funds, stock funds are usually leaved in advance. It is also called endogenous funding and it is priority in the use of company resources. And it can be able to reduce the corporate financing costs. Then it will choose the external form of debt financing or equity financing.

Currently, the literature focuses on the level of cash holdings and the value of cash holdings under the context of corporate governance. Equity dispersion as an important factor has Impact on corporate governance. And the size of equity dispersion will has a far-reaching impact on internal control, management model and corporate performance. This article is from the perspective of equity dispersion to analyze the company's cash holdings and firm performance.

The follow-up arrangements are as follows: The second part is related literature and hypothesis development, and the third part is the research design, the fourth part of the empirical evidence and discussion, the fifth part is the conclusion.

\section{RELATED LITERATURE AND HYPOTHESIS DEVELOPMENT}

About the motives of corporate cash holdings can be divided into four categories: transaction motive, the precautionary motive, the tax motive and the agency motive. Transaction motive refers to enterprises in the production process requires the non-cash assets converting into cash assets and cash converting into non-cash assets (Baumol (1952), Miller and Orr (1966)). Precautionary motive refers to the cash must be held for a better future of enterprise projects, or to respond future adverse environment that may occur. And due to information asymmetry between internal and external business, resulting in higher cost of funding, it must be held in cash, too (Opler er al.1999). Agency motive appears in the process of development of modern enterprise of separation between owners and managers. In the context of separation between owners and managers, a business manager has motive and conditions to spend more company's cash, even it is 
inefficient (Dittmar et al.2003). The tax motive, Foley, Hartzell, Titman, and Twite (2007) find that U.S. corporations that would incur tax consequences associated with repatriating foreign earnings hold higher levels of cash. This is particularly true for affiliates for which the implied tax consequences of repatriation are the highest. Consequently, multinational firms are more likely to accumulate cash.

Dittmar and Mahrt-Smith (2007) divided the companies into two categories by the corporate governance of company is good or bad. They used empirical test to analyze the impact of corporate governance on corporate cash value and effects of cash usage. Studies found that the cash value of companies with poor corporate governance its only $0.42 \$$, while in good corporate governance, the control group, the cash value is 0.88 . The cash value of good corporate governance group is more than twice as the cash value of poor corporate governance group. In case of cash use, the use of cash from poor corporate governance group is to go out faster [2].

$\mathrm{Hu}$ Guo-liu, Liu Bao-jin, Ma Qing-ren (2006) propose theoretical hypothesis and use multiple regression method to test the relationship between the manager stake, the largest shareholder stake, state-owned or not shares, proportion of tradable shares and corporate cash holdings. Empirical results show that the level of cash holdings has a significant positive correlation with the proportion of tradable shares and the stake held by company managers. The rest of the test results are not significant [3].

Based on the above analysis, we propose hypotheses:

1a: The higher the dispersion of equity is, the less the amount of excess cash holdings is.

$1 \mathrm{~b}$ : The lower the equity dispersion is, the more the amount of excess cash holdings is.

From the perspective of outside investors, or in the future they may become the company's shareholders, their concern is the potential long-term value of the company. And the company's shareholding structure is the source of the potential value of the company, particularly concerned by external investor. If the degree of equity dispersion of a company is large, then it will connect outside investors and the company's future development, resulting in a community of interests. Outside investors for their own interests are involved in the company's decision-making, and thus they play outside supervisory role, and this oversight role is often more effective than government's. From the company's point of view, the company through introducing external strategic investors by selling part of company stake is conducive to revitalize the existing capital. Company can use of the capital market to change into a diversified ownership structure. And it also can form scientific decision-making mechanism and scientific internal control mechanism to overcome the shortcomings of rule by man. It is conducive to the sustainable development of the company, thereby enhancing performance of the company [4-5].

Wang Shan-shan (2012) used the data from Yunnan province of Chinese to study the corporate governance structure, management and control system. And she made appropriate recommendations for improvement for the Chinese group companies. Chen Xiao-yue, Xu Xiao-dong (2001) used from 1996 to 1999 in Shenzhen Stock Exchange listed companies (excluding the financial sector) for the study sample. Since that time Chinese laws and regulations concerning the substantive protections of small investors is rarely, and modern enterprise management mode is not very mature, so the authors demonstrated using empirical methods that shareholding structure of Chinese enterprises effects on performance are different with traditional western view. Overseas studies have shown that the higher the proportion of tradable shares can promote enterprise performance, and it is indeed the opposite for Chinese enterprises. Then after the constant improvement of China's capital market, the legal regulation of the capital market according to 1999 has been greatly improved. So now the proportion of external tradable shares is still negatively correlated with corporate performance? And dispersion equity and corporate performance is still negative correlation? Therefore, these issues remain to be further studied.

We propose hypotheses:

2a: The higher shareholding dispersion is, the stronger positive effect on investment performance is.

2b: The higher shareholding dispersion is, the stronger negative effect on investment performance is.

\section{RESEARCH DESIGN}

\section{A Sample selection and Data sources}

In this paper, we use company listed in the Shanghai and Shenzhen Stock Exchanges A-share from 2008 to 2010. The ownership information data are gathered from the Database of Financial data and Marketing Data of China Capital Market (CSMAR), which provides detailed information we needed. And we exclude relevant data in accordance with the following guidelines: Because of the special nature of the financial and insurance industry, we exclude related data from finance and insurance industry companies; Because of the data of ST, PT financial statements of listed companies are not comparable, we exclude related data from such companies; our final sample consists of 5365 observations. Meanwhile, in order to eliminate the influence of extreme values, we use the method of winsorize to process the samples between 0 to $1 \%$ and $99 \%$ to $100 \%$

\section{$B$ Research model and variable definitions}

In order to measure the relationship between the proportion of outside tradable shareholders and shareholding cash holdings, we are drawing Opler (1999) cash holding model of influencing factors. And we established following model (1) to test for hypothesis 1 .

$$
\begin{aligned}
\operatorname{Ln}\left(\frac{C_{i, t}}{A_{i, t}}\right)=\alpha_{0}+ & \alpha_{1} \operatorname{Div}_{i, t}+\alpha_{2} \operatorname{Size}_{i, t}+\alpha_{3} \frac{C_{i, t}}{A_{i, t}}+\alpha_{4} \frac{N W C_{i, t}}{A_{i, t}} \\
& +\alpha_{5} Q_{i, t}+\alpha_{6} \frac{\operatorname{Capex}_{i, t}}{A_{i, t}}+\alpha_{7} \operatorname{Lev}_{i, t}+\alpha_{8} D_{i, t} \\
& +\sum \text { Year }+\varepsilon_{i, t}(1)
\end{aligned}
$$

In order to measure the relationship between the proportion of external shareholder and corporate performance, we are drawing the model of Dittmar and Smith (2007), Faulkender 
and Wang (2006) and Wang Yanchao, etc. (2008). And we established following model (2) to test for hypothesis 2.

$$
\begin{aligned}
\mathrm{AR}_{\mathrm{i}, \mathrm{t}}=\beta_{0}+\beta_{1} \frac{\Delta \mathrm{C}_{\mathrm{i}, \mathrm{t}}}{\mathrm{A}_{\mathrm{i}, \mathrm{t}-1}}+\beta_{2} \mathrm{DIV}_{\mathrm{i}, \mathrm{t}}+\beta_{3} \mathrm{DIV}_{\mathrm{i}, \mathrm{t}} \times \frac{\Delta \mathrm{C}_{\mathrm{i}, \mathrm{t}}}{\mathrm{A}_{\mathrm{i}, \mathrm{t}-1}} \\
+\beta_{4} \frac{\Delta \text { Earnings }}{\mathrm{A}_{\mathrm{i}, \mathrm{t}-1}}+\beta_{5} \frac{\Delta \text { Netasset }_{\mathrm{i}, \mathrm{t}}}{\mathrm{A}_{\mathrm{i}, \mathrm{t}-1}} \\
+\beta_{6} \frac{\Delta \text { Sales }_{\mathrm{i}, \mathrm{t}}}{\mathrm{A}_{\mathrm{i}, \mathrm{t}-1}}+\beta_{7} \text { Lev }_{\mathrm{i}, \mathrm{t}}+\beta_{8} \frac{\mathrm{C}_{\mathrm{i}, \mathrm{t}-1}}{\mathrm{~A}_{\mathrm{i}, \mathrm{t}-1}} \\
\\
\times \frac{\Delta \mathrm{C}_{\mathrm{i}, \mathrm{t}}}{\mathrm{A}_{\mathrm{i}, \mathrm{t}-1}}+\gamma \text { Year }+\varepsilon_{\mathrm{i}, \mathrm{t}}(2)
\end{aligned}
$$

\begin{tabular}{|c|c|c|}
\hline variable names & symbols & $\mathrm{d}$ \\
\hline cash holdings & $\mathrm{C}$ & $\mathrm{n}$ \\
\hline equity dispersion & Div & 1 \\
\hline company Size & Size & $\mathrm{tl}$ \\
\hline cash flow & $\mathrm{CF}$ & $\mathrm{n}$ \\
\hline net working capital & NWC & $\mathrm{c}$ \\
\hline Tobin's Q & $\mathrm{Q}$ & $\mathrm{n}$ \\
\hline capital expenditure & Capex & $\begin{array}{l}\text { li } \\
\text { ir }\end{array}$ \\
\hline asset-liability ratio & Lev & to \\
\hline ratio of dividend payout & $\mathrm{D}$ & $\mathrm{d}$ \\
\hline total assets & $\mathrm{A}$ & $\mathrm{a}$ \\
\hline changes in net profit & $\Delta$ Earnings & $\mathrm{n}$ \\
\hline changes in non-cash assets & $\Delta$ Netasset & $\mathrm{n}$ \\
\hline changes in revenue & $\Delta$ Sales & $\mathrm{r}$ \\
\hline stock returns & AR & $\mathrm{a}$ \\
\hline
\end{tabular}

Symbols, variable names, and descriptions are shown in Table 1.

TABLE I VARIABLE AND DESCRIPTION OF MODEL 1

\section{description} monetary funds

1- proportional share of the largest shareholder the natural logarithm of total assets of listed companies net profit + depreciation + amortization current assets - current liabilities - cash market value / book value

listed companies through the acquisition of fixed assets, intangible assets, cash expenditures and other long-term assets total liabilities / total assets dividend payout ratio of listed companies a listed company's total assets net income for the period $\mathrm{t}$ - net income for the period $\mathrm{t}-1$ non-cash assets for the period $\mathrm{t}$ - non-cash assets for the period $\mathrm{t}-1$ revenue for the period $\mathrm{t}$ - revenue for the period $\mathrm{t}-1$ annual rate of stock return of ultimate control rights and cash flow rights. The higher degree of separation of ultimate control rights and cash flow rights is. The more severe agency conflicts are. And it is more prone to arising tunneling phenomenon. It affected negatively performance of the company, resulting in a decline in value of the company. We must consider these two opposing effects affecting of business performance. Because of the negative effects is bigger than positive effects, so that the regression coefficient is negative.

The estimated coefficient of DIV for group B is -0.378 . The sign of the coefficient negative as expected. But it did not pass the test of significance. And we need to do further study. the test of significance.

\section{$B$ Equity dispersion and Corporate Performance}

As we can see from the table 3: The coefficient of DIV for group A is -1.164 statistically significantly at higher than the $1 \%$ level. The negative sign contradicted the previous assumptions. We believe that the following reasons for making the empirical results inconsistent with the assumptions. The size of the outside investors in the company is an ownership structure ultimately. Ownership structure affects the company's performance in two ways. On the one hand, diversified ownership structure of the company can form effective supervision. So it can have the positive effects on the performance of company. On the other hand, diversified ownership structure of the company can result in the separation 
TABLE II EQUITY DISPERSION AND CASH HOLDINGS

\begin{tabular}{|l|l|l|}
\hline & & \multicolumn{1}{|c|}{ Panel A } \\
\hline \multirow{2}{*}{ Constant $)$} & $-7.031 * * *$ & $-3.039 * * *$ \\
& $(-13.103)$ & $(-13.073)$ \\
\hline \multirow{2}{*}{ DIV } & -.641 & $.527 * * *$ \\
& $(-1.427)$ & $(3.275)$ \\
\hline \multirow{2}{*}{ SIZE } & $.204 * * *$ & -.005 \\
& $(10.717)$ & $(-.559)$ \\
\hline \multirow{2}{*}{ NFA } & $-.004 * *$ & -.070 \\
& $(-2.188)$ & $(-.527)$ \\
\hline \multirow{2}{*}{ CAPEXA } & .035 & $.226 * * *$ \\
& $(.985)$ & $(4.589)$ \\
\hline \multirow{2}{*}{ CA } & $1.473 * * *$ & .245 \\
& $(4.112)$ & $(1.053)$ \\
\hline \multirow{2}{*}{ Tobin's Q } & $5.187 * * *$ & $4.629 * * *$ \\
& $(45.307)$ & $(56.938)$ \\
\hline \multirow{2}{*}{ LEV } & $.009 * *$ & -.008 \\
\hline Year & $(2.370)$ & $(-.670)$ \\
\hline
\end{tabular}

Coefficients marked with $*, * *, * * *$ are significant at $10 \%, 5 \%$ and $1 \%$, respectively.

TABLE III EQUITY DISPERSION AND CORPORATE PERFORMANCE

\begin{tabular}{|c|c|c|}
\hline & Panel A & Panel B \\
\hline (Constant) & $\begin{array}{l}.736 * * \\
(2.550)\end{array}$ & $\begin{array}{l}.057 \\
(.317)\end{array}$ \\
\hline DIV & $\begin{array}{l}-1.164 * * * \\
(-3.349)\end{array}$ & $\begin{array}{l}-.378 \\
(-1.180)\end{array}$ \\
\hline$(\Delta$ Sales $) / A$ & $\begin{array}{l}.009 \\
(.298) \\
\end{array}$ & $\begin{array}{l}.057 * \\
(1.753)\end{array}$ \\
\hline$(\Delta$ Earnings $) / A$ & $\begin{array}{l}.000^{*} \\
(-1.659)\end{array}$ & $\begin{array}{l}.003 \\
(.205)\end{array}$ \\
\hline Lev & $\begin{array}{l}.014 \\
(1.272)\end{array}$ & $\begin{array}{l}.010 \\
(1.235)\end{array}$ \\
\hline Netasset & $\begin{array}{l}.434 * * * \\
(4.856)\end{array}$ & $\begin{array}{l}.226^{*} \\
(1.625)\end{array}$ \\
\hline $\mathrm{DIV}^{*} \Delta \mathrm{C} / \mathrm{A}$ & $\begin{array}{l}1.200 \\
(1.193)\end{array}$ & $\begin{array}{l}-1.063 \\
(-.977)\end{array}$ \\
\hline$\Delta \mathrm{C} / \mathrm{A}$ & $\begin{array}{l}-.713 \\
(-.925)\end{array}$ & $\begin{array}{l}.529 \\
(1.142)\end{array}$ \\
\hline $\mathrm{C}(\mathrm{I}, \mathrm{t}-1)^{*} \Delta \mathrm{C}$ & $\begin{array}{l}-.020 * \\
(-2.529)\end{array}$ & $\begin{array}{l}-.017 \\
(-1.346)\end{array}$ \\
\hline Year & control & control \\
\hline
\end{tabular}

\section{CONCLUSION}

With 2012 2016 years in Shanghai and Shenzhen Stock Exchange A shares listing corporation as research samples, we used empirical method to study relationship of cash holdings, equity dispersion and corporate performance through control of the capital structure and other firm characteristics.

By drawing Opler (1999) cash holding model of influencing factors, we studied the relationship of equity dispersion and cash holdings. The empirical research results
Coefficients marked with $*, * *, * * *$ are significant at $10 \%, 5 \%$ and $1 \%$, respectively. show that the smaller equity dispersion is, the higher cash company holds. It indicated that the company did not form an effective regulatory system. So companies are more likely to encroach cash, confirmed the previous hypothesis $1 \mathrm{~b}$. The sign of the coefficient of DIV for group B is negative as expected. But it did not pass the test of significance. And we need to do further study.

By drawing the model of Dittmar and Smith (2007), Faulkender and Wang (2006) and Wang Yanchao, etc. (2008), we test equity dispersion effect on corporate performance. The 
result of negative sign contradicted the previous assumptions. The reason of it can be explain by following reasons: On the one hand, diversified ownership structure of the company can form effective supervision. So it can have the positive effects on the performance of company. On the other hand, diversified ownership structure of the company can result in the separation of ultimate control rights and cash flow rights. The higher degree of separation of ultimate control rights and cash flow rights is. The more severe agency conflicts are. And it is more prone to arising tunneling phenomenon. It affected negatively performance of the company, resulting in a decline in value of the company. We must consider these two opposing effects affecting of business performance. Because of the negative effects is bigger than positive effects, so that the regression coefficient is negative.

\section{REFERENCES}

[1] Peng Taoying, Zhou Wei, Why Chinese Public Listed Corporations Hold High-scale Cashes? ACCOUNTING RESEARCH 2006(5):42-49.

[2] Dittmar A., and Mahrt-Smith J. Corporate Governance and the Value of Cash Holdings. Journal of Financial Economics, 2007(83): 599634.

[3] HU Guoliu, LIU Baojin, MA Qingren, An Empirical Study on the Relationship between Ownership Structure and Cash Holdings. The Theory and Practice of Finance and Economics, 2006. 27(4):39-44.

[4] YU Dongzhi, HU Guoliu, WANG Huacheng, Analysis of Decision-Making on Cash Holding by Enterprises and Corporate Governance [J]. Finance Forum,2006 11(10):28-35. (In Chinese)

[5] Yang Yang, Entrepreneurship impact on financial performance - adjust the industrial environment variable Dongjiang Journal, 2012(3):98-104 (In Chinese) 